\title{
Individual-, home- and preschool-level correlates of preschool children's sedentary time
}

Suvi Määttä ${ }^{1,2^{*}}$ (D), Hanna Konttinen ${ }^{3,2}$, Rejane Augusta de Oliveira Figueiredo ${ }^{1}$, Ari Haukkala ${ }^{2}$, Nina Sajaniemi ${ }^{4}$, Maijaliisa Erkkola ${ }^{3}$ and Eva Roos ${ }^{1,3,5}$

\begin{abstract}
Background: Prechoolers' significant portions of sedentary time (ST) is a public-health concern due to its high prevalence and negative health consequences. However, few studies have explored correlates of preschoolers' ST covering individual-, home- and preschool- factors within one study. The aim of this study was to identify the associations between multiple individual-, home- and preschool-level factors and preschoolers' ST. In addition, it was studied how much individual-, home- and preschool-level factors explained the variance in children's ST.

Methods: A total of 864 children aged three to six, their parents and 66 preschools participated in the crosssectional DAGIS study, which occurred between 2015 and 2016. The children wore an accelerometer for 1 week. Guardians, principals and early educators completed questionnaires covering the potential correlates of children's ST, for example, temperament, practices, self-efficacy and regulations. Multilevel regression analyses were conducted in multiple steps; calculation of marginal and conditional $R^{2}$ values occurred in the final phase.

Results: Of the 29 studied correlates, the following factors remained significant in the final models. Being a boy $(p<0.001)$ and having high levels of surgency temperament $(p<0.001)$ were associated with lower ST. Regarding the home setting, frequent co-visits in physical activity (PA) places $(p=0.014)$ were associated with lower ST. Higher parental perceived barriers related to children's outside PA $(p=0.032)$ was associated with higher ST. None of the preschool setting factors remained significant in the final model. Approximately $11 \%$ of the variance in children's ST was attributed to factors related to the individual level whereas $5 \%$ was attributed to home-level factors; and 2\% to preschool-level factors.

Conclusions: This study identified a set of correlates of preschool children's ST. Interventions aimed at reducing children's ST should develop strategies targeting established correlates of preschoolers' ST covering individual-, home- and preschool-level factors. The preschool-level factors included in this study explained little the variance in children's ST. However, the included measures may not have captured the essential preschool-level factors that specifically influence children's ST. Therefore, more studies are needed regarding potential preschool-level factors.
\end{abstract}

Keywords: children, preschool, home, parents, sedentary time, socioecological model

*Correspondence: suvi.maatta@folkhalsan.fi; Suvi.maatta@folkhalsan.fi

${ }^{1}$ Folkhälsan Research Centre, Samfundet Folkhälsan, Topeliuksenkatu 20,

00250 Helsinki, Finland

${ }^{2}$ Faculty of Social Sciences, University of Helsinki, P.O.box 66, FI-00014

University of Helsinki, Helsinki, Finland

Full list of author information is available at the end of the article

(c) The Author(s). 2020 Open Access This article is distributed under the terms of the Creative Commons Attribution 4.0 International License (http://creativecommons.org/licenses/by/4.0/), which permits unrestricted use, distribution, and reproduction in any medium, provided you give appropriate credit to the original author(s) and the source, provide a link to the Creative Commons license, and indicate if changes were made. The Creative Commons Public Domain Dedication waiver (http://creativecommons.org/publicdomain/zero/1.0/) applies to the data made available in this article, unless otherwise stated. 


\section{Background}

Preschool-age children, generally aged between three and five, spend about half of their waking hours in sedentary [1] . Sedentary time (ST) is defined as the time spent in sedentary behaviors (SB); SB is defined as any waking behavior characterized by an energy expenditure of less than or equal to 1.5 metabolic equivalents (METs) while in a sitting, reclining or lying posture [2]. ST can therefore consist of multiple different types of SBs (e.g. screen time, playing still and reading) that can accumulate throughout the week and across multiple settings. Higher ST in adulthood is associated with negative health consequences such as chronic disease outcomes and all-cause mortality, although high levels of daily physical activity (PA) may eliminate these risks [3-5]. The evidence of health consequences of overall $\mathrm{ST}$ in preschool-age is less conclusive [6]. However, as many other health behavior habits, SB habits are rooted in early childhood and tend to track later in life [7]. As preschool children spend significant proportions of their time in sedentary, it is relevant to study the factors associated with children's ST [1, 8, 9]. For instance, studies have identified the role of home and preschool settings in influencing preschool children's ST, stating that children in center-based care such as preschool are highly sedentary compared to children cared for at home; however, the opposite results have also been found $[1,10]$. The difference in these results may relate to different ST measurement methods or cultural context of studies. This dissimilarity also underlines the importance of understanding which factors may cause variations in preschool children's ST.

According to the socioecological models of health behaviors [11], multiple factors at a variety of ecological levels can influence ST. These correlates may be positioned at individual levels: for example, biological and temperament characteristics; or at environmental settings:such as home and preschool [11-13]. The environmental setting can consist of the physical environment (the type of available physical environment), social environment (the type of attitudes and beliefs of significant others) and, regarding preschool, also the organizational environment (the type of rules and regulations) [14]. Due to the early developmental stage of preschool children, children are highly receptive and dependent on their caregivers in their daily movement behaviors (e.g. ST, and PA) [15]. Caregivers in both of these settings, such as guardians, principals and early educators, can help to shape children's possibilities to conduct movement behaviors through a variety of social environmental mechanisms, including encouragement, beliefs and attitudes, role modelling, rules and regulations, involvement and facilitation [16, 17]. Thus, it is important to understand which social environmental factors in both settings are associated with children's ST.
Although the number of studies regarding correlates of preschool children's ST has risen following Hinkleys' et al review in 2010 [18], insufficient evidence prevents drawing conclusions about the correlates of ST. For instance, numerous studies have recognized that girls are more sedentary than boys. However, the influence of other child characteristics such as temperament on preschool children's ST is less studied [1, 19]. Similarly, a recent review highlights the lack of knowledge about preschool social- and organizational level factors associated with children's ST [20]. Slightly more knowledge exists of associations between social environment in the home setting and preschool children's screen time as an indicator of ST [21]; however, the correlates of screen time and overall ST seem to be distinct [22]. Another relevant aspect of social environment is socioeconomic status (SES) and its associations with children's behaviors [23]. Studies indicate associations between lower parental SES or lower neighborhood SES, and a higher risk of an unhealthier lifestyle and cardiovascular disease [24-27]. However, studies regarding the associations between parental or neighborhood SES and children's ST are scarce, with contradictory findings, which can result from the variety of possible ways to measure SES $[24,28]$.

Many of these previous studies have also explored the influence of either preschool OR home; the influence of the combination of these settings is lacking. Following the principles of socioecological models, these settings interact with each other influencing children's behavior [14]. Thus, a recent systematic review encourages the exploration of potential correlates across multiple levels of influence of socioecological model within one study [29]. Based on these above-mentioned considerations, this study aims to investigate which individual-, homeand preschool-level factors are associated with preschool children's ST. In addition, this study aims to discover the extent to which individual-, home- and preschoollevel factors explain variance in children's ST.

\section{Methods \\ Study design and population}

The cross-sectional DAGIS (Increased Health and Wellbeing in Preschools) survey was conducted in eight municipalities in Southern and Western Finland in 2015 and 2016. More detailed information about the study purposes and the flow chart of participation in this study can be read elsewhere $[30,31]$. Briefly, the main recruitment criterion for the randomly invited preschools was the existence of at least one preschool group with children aged between three and six. In the chosen municipalities, 86 preschools (51\% of those invited) agreed to participate in the study, and organized the recruitment of families and children. A total of 983 guardians $(27 \%$ 
of contacted guardians) gave written permission for their child to participate in the study. Implementation of study procedures required participation of at least $30 \%$ of children in at least one preschool group in a preschool; 91 guardians had a child in a preschool with less than the $30 \%$ participation rate and were thus excluded from the study. In addition, 28 children did not have any data. A total of 864 (24\% of invited) children from 66 preschools (39\% of invited preschools) participated in the study. The University of Helsinki Ethical Review Board in the Humanities and Social and Behavioral Sciences approved the study procedures (6/2015, approved on 25th February, 2015).

\section{Measures}

\section{Children's sedentary time}

Children wore an Actigraph W-GT3X accelerometers (Actigraph, LLC, Fort Walton Beach, Florida) for one week. Actigraphs have been validated and used extensively as an objective measure of PA and ST for different age groups and in different contexts [32-34]. Research group set the accelerometers on the children's right hip during the first day of measurement in the preschool. After data collection, the epoch length was set at $15 \mathrm{~s}$. Periods of $10 \mathrm{~min}$ or more at zero accelerometer counts were considered non-wear times and were excluded [35]; however, possible nap-times were not excluded. The analyses applied the Evenson ST cut-point (0-25 counts per $15 \mathrm{~s}$ ) [36], a renonwned estimate of freeliving ST [37, 38]. We set the following accelerometer wear-time criteria for children in the analyses: at least 600 min of wear time each day; at least four days with at least one weekend day during a measurement week. Because wearing hours varied between children, the variable was adjusted for the wearing hours so that the overall ST minutes was divided by the the total accelerometer wearing time and multiplied by 60 to create outcome variable expressed as average minutes per hour $(\mathrm{min} / \mathrm{h})$. Consequently, the measure used in this study indicates the average children's ST minutes in one hour.

\section{Individual level}

Research group measured the height, weight and waist circumference of participating children in the preschool. These measurements allowed calculation of children's body mass index (BMI) by dividing the weight in kilograms by the square of the height in meters. Each guardian reported their child's age and gender in the guardian's questionnaire. Guardians were given a separate questionnaire regarding children's temperament, which asked guardians to consider their children's reactions to 36 situations in the past six months. The questionnaire is based on a short form of the Child Behavior Questionnaire for children aged three to seven
[39], which has demonstrated satisfactory internal consistency, criterion validity and longitudinal stability and provides a comprehensive assessment of children's temperament [39]. The separate 36 items are typically coded into three summary scores to illustrate separate temperament domains: negative affectivity, effortful control and surgency. A child with a high level of negative affectivity is typically angry and fearful with a lowered mood and low soothability. A child with a high level of effortful control enjoys low-intensity activities and is characterized by increased attentional capacities, inhibitory control. A child with high surgency levels is impulsive, enjoys situations with high stimulus intensity and feels comfortable in social situations [39].

\section{Home level}

One guardian in each family completed the guardian's questionnaire that covers attitudes, beliefs, self-efficacy, practices and availability of items related to children's energy balance-related behaviors (EBRBs). This questionnaire also had multiple questions about family SES. Guardians could complete the questionnaire either online or on paper. The questions were based on formative work of the research group, the previously validated questions and items specific to the Finnish context [40-43]. The questionnaire included items related either to screen time, ST or PA because, as yet, only a limited number of associations between ST and potential correlates among preschool children have been recognized. In addition, we chose a mothers' education as the indicator of parental SES because it seems to be the strongest, reliable and most consistent determinant of children's health behaviors and childhood obesity $[24,44,45]$. Table 1 presents all the items used in this study. The selection of these home setting measures for this study was based on the following criterias: a) the included measures capture social environment related to children's ST extensively, b) the measures are measured similarly (or almost similarly) in preschool level, and c) the measures are relevant to measure based on the previous research findings.

\section{Preschool level}

Multiple questionnaires were used to measure the preschool setting. Principals were asked to complete a web-based questionnaire covering both the rules and regulations related to EBRBs in their preschool and their own attitudes and beliefs about children's EBRBs. Because each preschool group in a preschool can define their own practices, we had an additional questionnaire for each preschool group that more precisely measured their group-based practices related to children's EBRBs. One early educator in each preschool group completed this paper-based questionnaire. The questions in both questionnaires were based on formative work of the 
Table 1 Summary of measures included in the analysis

\begin{tabular}{|c|c|c|}
\hline Level of influence & Variable & Survey items in the questionnaire \\
\hline \multirow[t]{6}{*}{ Individual level } & Gender & \\
\hline & Age & \\
\hline & BMI & \\
\hline & Surgency & $\begin{array}{l}\text { Based on established codings (see } \\
\text { Putnam \& Rothbart, 2006). E.g., likes } \\
\text { going down high slides or other } \\
\text { adventurous activities; often rushes into } \\
\text { new situations; }\end{array}$ \\
\hline & Negative affectivity & $\begin{array}{l}\text { Based on established codings (see } \\
\text { Putnam \& Rothbart, 2006). E.g., gets } \\
\text { angry when s/he cannot find something } \\
\text { s/he wants to play with; becomes upset } \\
\text { when loved relatives or friends are } \\
\text { getting ready to leave following a visit }\end{array}$ \\
\hline & Effortful control & $\begin{array}{l}\text { Based on established codings (see } \\
\text { Putnam \& Rothbart, 2006). E.g., when } \\
\text { drawing or coloring in a book, shows } \\
\text { strong concentration; prepares for trips } \\
\text { and outings by planning things s/he will } \\
\text { need. }\end{array}$ \\
\hline
\end{tabular}

\begin{tabular}{lll} 
Scale, coding, and Cronbach alpha if relevant & Descriptive & $N$ \\
\hline $\begin{array}{ll}1=\text { girl, } 2=\text { boy } \\
\text { Continuous }\end{array}$ & Mean 4.74 & 864 \\
& SD 0.89 & \\
& Mean 15.87 & 809 \\
& SD 1.42 &
\end{tabular}

Scale from extremely untrue of your Mean 4.69

SD 0.09

child (1) to extremely true of your child

(7), Cronbach alpha 0.80

Scale from extremely untrue of your

Mean 3.70

SD 0.88

Home level

Parental beliefs Parental self-efficacy and attitudes
How confident are you that you could do the following? a) I can get my child to do something physically active no matter how busy his/her day is. b) I can get my child to be physically active no matter what the weather is like. c) I can get my child to be physically active even if he/she wants to use electronic devices. d) I can get my child to be physically active even if he/she wants to stay inside. e) I can get my child to be physically active even when there are no other children playing outside.

Parental self-efficacy for limiting children's screen time ${ }^{1}$

Parental attitude for importance of PA

Parental attitude toward societal pressures for screen time ${ }^{1}$

Parental perceived barriers related to children's outside PA'
How much do you agree or disagree with the following statements? a) I am concerned about my child's use of electronic devices. b) I find it difficult to limit my child's screen time if he/she does not want and starts whinging. c) I find it difficult to restrain myself from using electronic devices when my child is around.

How much do you agree or disagree with the following statement? a) It is gets enough PA each day.

How much do you agree or disagree with the following statements? a) Sport as a hobby and the related costs (e.g., equipment, materials, subscription fees) are too expensive. b) There is pressure from society to purchase and use different electronic devices. c) It is important for my child to learn how to use electronic devices, because I am not very good at using them myself.

How much do you agree or disagree with the following statements? a) Poor weather limits my child's opportunities to play outside. b) I find it difficult to let my child be physically active outside as I important for me to make sure my child
The answer options ranged from

(5). The statements were combined and divided by the number of items.

Cronbach alpha 0.62

The answer options ranged from

Mean 1.9

strongly disagree (1) to strongly agree (5). The statements were combined and divided by the number of items. Cronbach alpha 0.46

The answer option ranged from strongly disagree (1) to strongly agree (5). In the analyses, the 'somewhat disagree' was treated as a reference category as there were no 'strongly disagree' answers.

The answer options ranged from SD 0.75 strongly disagree (1) to strongly agree (5). The statements were combined and divided by the number of items. Cronbach alpha 0.34

The answer options ranged from strongly disagree (1) to strongly agree (5). The statements were combined and divided by the number of items. Cronbach alpha 0.36
Mean 4.34 
Table 1 Summary of measures included in the analysis (Continued)

\begin{tabular}{lll}
\hline Level of influence & Variable & Survey items in the questionnaire \\
\hline & & $\begin{array}{l}\text { always have to be there to supervise him } \\
\text { her. }\end{array}$ \\
& $\begin{array}{l}\text { Parental beliefs of } \\
\text { unhealthy energy } \\
\text { balance-related } \\
\text { behaviors (EBRBs) } \\
\text { as a problem }\end{array}$ & $\begin{array}{l}\text { To what extent do you think the } \\
\text { following matters are generally a problem } \\
\text { among 3-to-6-year-old children? a) Being } \\
\text { overweight. b) Excessive screen time. c) }\end{array}$ \\
& $\begin{array}{l}\text { Physical inactivity } \\
\text { Rules for limiting }\end{array}$ & $\begin{array}{l}\text { Do you have limits on how much time } \\
\text { Parenting } \\
\text { practices }\end{array}$ \\
children's screen time & $\begin{array}{l}\text { your child can spend: a) Watching } \\
\text { television. b) Using other screens. }\end{array}$
\end{tabular}

Scale, coding, and Cronbach alpha if relevant Descriptive

Parental practice for allowing child run around inside

Parental screen use in front of children
How much do you agree or disagree with the following statement? a) My child is allowed to run around and be physically active inside our house.

Approximately how many hours a day do YOU usually use electronic devices during leisure time when your child is around a) During weekdays. b) During weekends.
Mother's educationa leve
Parental PA in front of children

Frequent co-visits in PA places
Preschool level

Principals' beliefs and attitudes
Principals' personal interest in health

Principals' attitude about the importance of children's PA

Principals' attitude about the importance of decreasing children's sedentary time

Principals' self-efficacy for influencing children's behaviors
The highest educational attainment on a seven-item list:

(1) comprehensive school (2) vocational school (3) high school (4) bachelor's degree or college (5) master's degree and (6) licentiate/doctor (7) other. following places with at least one adult i the family? a) Nature/forest. b) Park and playground. c) Own yard. d) An indoor facility

Answer options (per day): $1=$ none, $2=$ less than $30 \mathrm{~min}, 3=30 \mathrm{~min}-1 \mathrm{~h}, 4=1-2$ h, $5=3-4 h, 6=5 \mathrm{~h}$ or more. The items were recoded so that $1=$ less than 30 $\min , 2=30-60 \mathrm{~min}, 3=$ more than 60 min, and they were combined into one variable. This sum variable was recoded into three categories: $1=$ less than 30 $\min , 2=30-60 \min , 3=$ more than $60 \mathrm{~min}$.

Answer options: never (1), 1-2 times (2), 3-4 times (3), 5-6 times (4) and daily (5).

The original answer options (less than once a month (1), 1-3 times per a month (2), 1-2 times a week (3), 3-4 times a week (4), 5-6 times a week (5) and daily (6)) were recoded to average weekly visits together at least with one parent in parks, forests/nature, own yard and indoor sport facilities.

The response options were re-organized into three groups: a low education was defined as comprehensive schooling (usually from ages 7-16) to secondary education (usually ages 16-19); a medium level refers to a bachelor's degree; and a high education as at least a master's degree.

How much do you agree or disagree with the following statement? a) I am personally interested in nutrition, PA, and health.

How much do you agree or disagree with the following statement? a) In my opinion, it is important to increase children's PA in preschool.

How much do you agree or disagree with the following statement? a) In my opinion, it is important to decrease children's sedentary time in preschool.

To what extent can you, as the principal impact the following? a) How physically active the children are. b) The number of The answer options ranged from strongly
disagree (1) to strongly agree (5). In the analyses, the 'either agree or disagree' was treated as a reference category as there were no strongly disagree or somewhat disagree answers. disagree (1) to strongly agree (5). disagree (1) to strongly agree (5).
The answer options ranged from not at all a problem (1) to a very big problem (5). The statements were combined and divided by the number of items. Cronbach alpha 0.75

The three answer options were "yes," "no," and "don't have the equipment." This question was recoded so that "don't have the equipment" answers [for the television $N=20(2.5 \%)$ and for other equipment $N=15(2 \%)$ ] were set as missing values.

Mean 3.27

800

SD 0.65

Yes $(0)=74 \%$,

$n=565$

No $(1)=26 \%$

$n=197$

Mean 4.38

SD 0.90

Less than 30

$\min (1)=$

$33 \%, n=263$

30-60 min

(2) $=40 \%$,

$n=320$

More than

$60 \mathrm{~min}$

(3) $=27 \%$,

$n=213$

Mean 2.6

SD 1.19

Mean 7.8

SD 3.8

Low education

Medium

education

$41 \%, n=353$

High

education

$29 \%, n=250$

Mean 4.63 58

Mean 4.77

SD 0.53

Mean 4.63

SD 0.66 
Table 1 Summary of measures included in the analysis (Continued)

\begin{tabular}{|c|c|c|c|c|c|}
\hline Level of influence & Variable & Survey items in the questionnaire & Scale, coding, and Cronbach alpha if relevant & Descriptive & $\mathrm{N}$ \\
\hline & & $\begin{array}{l}\text { electronic devices in the preschool. c) The } \\
\text { use of electronic devices in the preschool. }\end{array}$ & & & \\
\hline & $\begin{array}{l}\text { Principals' beliefs of } \\
\text { unhealthy EBRBs as a } \\
\text { problem }\end{array}$ & $\begin{array}{l}\text { To what extent do you think that } \\
\text { following matters are generally a problem } \\
\text { among 3-to-6-year-old children? a) Being } \\
\text { overweight; b) Excessive screen time; c) } \\
\text { Physical inactivity }\end{array}$ & $\begin{array}{l}\text { The answer options ranged from not at } \\
\text { all a problem } \\
\text { (1) to a very big problem (5). } \\
\text { The statements were combined and } \\
\text { divided by the number of items. } \\
\text { Cronbach alpha } 0.70\end{array}$ & $\begin{array}{l}\text { Mean } 3.04 \\
\text { SD } 0.62\end{array}$ & 58 \\
\hline \multirow[t]{6}{*}{$\begin{array}{l}\text { Organizational } \\
\text { policies and } \\
\text { practices }\end{array}$} & $\begin{array}{l}\text { Frequency of visits in } \\
\text { PA places }\end{array}$ & $\begin{array}{l}\text { How often does your preschool group } \\
\text { visit the following places: a. Forest/place } \\
\text { for a nature trip. b. Park. c. Neighborhood } \\
\text { sports facilities or Gym. d. Other indoor } \\
\text { facility for PA. Partly open-ended question } \\
\text { so that early educator openly reported } \\
\text { the times, but selected the frequency } \\
\text { from options: weekly, monthly, yearly. }\end{array}$ & $\begin{array}{l}\text { Recoded so that average weekly level } \\
\text { visits in nature/forests, parks, gym (not } \\
\text { own) or neighborhood sport facilities } \\
\text { was calculated }\end{array}$ & $\begin{array}{l}\text { Mean } 1.74 \\
\text { SD } 1.35\end{array}$ & 142 \\
\hline & Screen time policy & $\begin{array}{l}\text { Do you have instructions on the } \\
\text { following themes in your preschool: a) } \\
\text { Permitted screen time for the children. b) } \\
\text { Supervision of the children's use of } \\
\text { electronic devices. c) Staff's use of own } \\
\text { electronic devices. d) In-service training } \\
\text { for the staff on screen time. e) Bringing } \\
\text { electronic devices to the preschool on a } \\
\text { toy day (e.g., a tablet) }\end{array}$ & $\begin{array}{l}\text { The original answer options }(1=\text { no } \\
\text { instructions, } 2=\text { oral instructions, } 3=\text { own } \\
\text { written instructions and } 4=\text { other written } \\
\text { instructions) were summed up so that a } \\
\text { maximum score } 20 \text { means that all asked } \\
\text { items are other written instructions; the } \\
\text { possible range in scores was between } 4 \\
\text { and } 20 \text {. }\end{array}$ & $\begin{array}{l}\text { Mean } 8.55 \\
\text { SD } 2.50 \text {, } \\
\text { measured } \\
\text { minimum } 5 \\
\text { and } \\
\text { maximum } 15\end{array}$ & 58 \\
\hline & $\begin{array}{l}\text { Guidance for families } \\
\text { policy }\end{array}$ & $\begin{array}{l}\text { Do you have instructions on following } \\
\text { themes in your preschool: a) Guidance for } \\
\text { families on children's PA (indoors and } \\
\text { outdoors). b) Guidance for families on } \\
\text { screen time. }\end{array}$ & $\begin{array}{l}\text { The original answer options }(1=\text { no } \\
\text { instructions, } 2=\text { oral instructions, } 3=\text { own } \\
\text { written instructions and } 4=\text { other written } \\
\text { instructions) were summed up so that a } \\
\text { maximum score } 8 \text { means that all asked } \\
\text { items are other written instructions; the } \\
\text { possible range in scores was between } 2 \\
\text { and } 8 \text {. }\end{array}$ & $\begin{array}{l}\text { Mean } 3.27 \\
\text { SD 1.66, } \\
\text { Measured } \\
\text { minimum } 2 \\
\text { and } \\
\text { maximum } 8\end{array}$ & 58 \\
\hline & Healthy PA policy & $\begin{array}{l}\text { Do you have instructions on the } \\
\text { following themes in your preschool: a) } \\
\text { Children's daily amount PA indoors and } \\
\text { outdoors. b) Limiting children's sedentary } \\
\text { behavior. c) Staff's practices in } \\
\text { encouraging PA. d) Planned physical } \\
\text { education for children. e) In-service } \\
\text { training for staff on children's PA } \\
\text { (indoors and outdoors). f) Ensuring } \\
\text { sufficient outdoor play time regardless } \\
\text { of the weather conditions. g) Limiting } \\
\text { children's PA/running outdoors. } \\
\text { h) Limiting children's PA/running indoors. }\end{array}$ & $\begin{array}{l}\text { The original answer options }(1=\text { no } \\
\text { instructions, } 2=\text { oral instructions, } 3=\text { own } \\
\text { written instructions and } 4=\text { other written } \\
\text { instructions) were summed up so that a } \\
\text { maximum score } 32 \text { means that all asked } \\
\text { items are other written instructions; the } \\
\text { possible range in scores was between } 4 \\
\text { and } 32 \text {. }\end{array}$ & $\begin{array}{l}\text { Mean } 19.55 \\
\text { SD } 5.37 \\
\text { Measured } \\
\text { minimum } 10 \\
\text { and } \\
\text { maximum } 32\end{array}$ & 58 \\
\hline & $\begin{array}{l}\text { Active play possibility } \\
\text { during free play }\end{array}$ & $\begin{array}{l}\text { Do children always have the possibility to } \\
\text { play actively during free play time? a) In } \\
\text { the group facilities. b) Elsewhere than in } \\
\text { the group facilities }\end{array}$ & $\begin{array}{l}\text { Combined measure so that Yes }= \\
\text { possible to play actively at least in one } \\
\text { place, or no = no possible at all. Due to } \\
\text { answer distribution, this measure was } \\
\text { recoded so that } 1=\text { no at all possible, } \\
0=\text { others }\end{array}$ & $\begin{array}{l}14,5 \% \text { had } \\
\text { no active } \\
\text { play } \\
\text { possibility, } \\
n=21 \\
\text { groups }\end{array}$ & 142 \\
\hline & $\begin{array}{l}\text { Preschool } \\
\text { neighborhood } \\
\text { socioeconomic } \\
\text { status (SES) }\end{array}$ & $\begin{array}{l}\text { The score for the SES of each preschool } \\
\text { was calculated using database } \\
\text { information on a) income (median } \\
\text { population income in the area } \\
\text { logarithmically transformed), b) } \\
\text { educational level (percentage of over 18- } \\
\text { year-olds whose highest educational level } \\
\text { was a master's degree or beyond), and c) } \\
\text { area unemployment rate. The } \\
\text { unemployment rate was coded inversely } \\
\text { to get higher values for lower } \\
\text { unemployment rates. }\end{array}$ & $\begin{array}{l}\text { The preschool SES score for each } \\
\text { preschool neighborhood was calculated } \\
\text { by taking the mean value of the } z \text { scores } \\
\text { on income, educational level and } \\
\text { unemployment rate. The score was then } \\
\text { divided into tertiles representing low, } \\
\text { middle, and high preschool SES. }\end{array}$ & $\begin{array}{l}31,5 \% \text { in low } \\
\text { SES, } n=21 \\
30,7 \% \text { in } \\
\text { middle SES, } \\
n=21 \\
37,8 \% \text { in } \\
\text { high SES, } n=24\end{array}$ & 66 \\
\hline
\end{tabular}

${ }^{1}$ Based on loadings in the factor analysis

PA Physical activity, EBRBs Energy balance-related behaviors, SES Socioeconomic status, SD Standard deviation 
research group, the previously validated questions and items developed suitable for the Finnish context [46-48]. The preschool neighborhood SES was obtained from Statistics Finland. This grid database contains coordinatebased statistical data calculated on a map grid within a one-kilometer radius from the participating preschools. Table 1 presents all the items used in this study. The selection of these home setting measures for this study was based on the following criterias: a) the included measures capture social or organisational environment related to children's ST extensively, b) the measures are measured similarly (or almost similarly) in home level, and c) the measures are relevant to measure based on the previous research findings.

\section{Covariates}

Covariates in the analyses were 'Children's average attendance at preschool' and 'Study season'. 'Children's attendance at preschool' was a composite score of the following questions in the guardians' questionnaires: 'How many days per week does your child attend preschool? ' and 'How many hours per day does your child usually attend preschool? '. The average children's daily attendance hours in preschool (hours/day) was formed by combining these measures. The 'Study season' measure was divided into three categories: $1=$ September - October, $2=$ November December, and 3 = January-April.

\section{Statistical analyses}

The descriptive statistics, factor analysis of sum variables and multicollinearity tests were conducted using the SPSS statistical program version 24 (SPSS Inc., Chicago, IL, USA). Multicollinearity was tested using tolerance and variance inflation factors. The results indicated no issues with multicollinearity.

Linear regression models examined the associations between explanatory factors and children's ST, with analyses conducted in multiple steps. First, the main effects of all the potential explanatory factors was individually examined. These regression models were conducted in Mplus version 7.14. (Muthen \& Muthen, 2017). MLR (maximum likelihood with robust standard errors) was used as an estimator in the analyses. These models accounted for clustering of children within families with participating siblings, preschools and preschool groups. If the responses were nested in the same higher-level unit, such as children attending the same preschool, multilevel design were applied. In these multilevel models, children were set as the first level unit, and the preschools or preschool groups as the second level unit. In addition, each individual level variable was groupmean centered $[49,50]$.

In the second phase, all the explanatory factors indicating association with ST $(P$-value $<0.10)$ from the previous phase were included in the same model. For this model, we calculated the marginal and the conditional $R^{2}$ as per Nakawaga and Schilzeth (2013). Marginal $R^{2}$ is the variance explained by fixed factors in the model, and conditional $R^{2}$ is the variance explained by fixed and random factors [51]. After estimating the model, the "sum square" of each fixed factor (independent variables) was used to calculate the explained variance for each independent variable. First, the percentage of explained variance between all fixed factors was calculated. As the fixed factors explained only $29.8 \%$ of the variance, variance explained was estimated to the full model.

\section{Results}

Of the 864 participating children, 773 children had valid accelerometer data for the analyses. Of them, $48 \%$ were girls. The average age of children with accelerometer data was 4 years and 7 months $(\mathrm{SD}=0.86)$.On average, the children had $28.1 \mathrm{~min}$ of ST per hour $(\mathrm{SD}=4 \mathrm{~min} /$ h). A total of 809 guardians completed the guardian's questionnaire. Of them, $88 \%$ were mothers and $57 \%$ of respondents completed the questionnaire online $(N=$ 461). Table 1 presents the mean and standard deviation for continuous explanatory variables and percentages for categorical explanatory variables.

Table 2 presents the results of the first models. All the 29 potential explanatory factors were included individually in the analyses. These first models indicated that being a boy $(p=0.000)$ and having high surgency temperament characteristics $(p=0.000)$ were associated with lower ST, whereas having high levels of effortful control was associated with higher $\operatorname{ST}(p=0.000)$. Regarding the home setting, the following factors were associated with children's lower ST: parental self-efficacy for activating child for PA $(p=0.036)$ and frequent visits together in PA places $(p=0.002)$. Parental perceived barriers related to children's outside PA $(p=0.001)$ was associated with children's higher ST.

Regarding the preschool setting, the following factors were associated with children's lower ST: more frequent visits in PA places $(p=0.047)$ and written policies about guidance for families $(p=0.039)$. Preschool principals' personal interest in health $(p=0.001$ in the comparison between strongly agree and neither agree or disagree) and principals' beliefs of unhealthy EBRBs as a problem $(p=0.021)$ were associated with children's higher ST.

Table 3 presents the results of the final models. Analysis of these models included the explanatory factors that showed at least some evidence of an association with the previous phase (total 11 factors). Of the individual level factors, being a boy $(p<0.001)$ and having high levels of surgency-type temperament $(p<0.001)$ was 
Table 2 Associations of each explanatory factor and children's sedentary time ( $\mathrm{min} / \mathrm{h}$ ) in multilevel linear regression models

\begin{tabular}{|c|c|c|c|c|c|c|}
\hline Level of influence & Variable name & $\beta$ & Lower 95\% Cl & Upper 95\% Cl & $p$-value & $\mathrm{N}$ \\
\hline \multirow[t]{6}{*}{ Individual level } & Gender & -0.98 & -1.47 & -0.49 & 0.000 & 718 \\
\hline & Age & 0.09 & -0.17 & 0.36 & 0.497 & 718 \\
\hline & BMI & -0.00 & -0.05 & 0.05 & 0.945 & 684 \\
\hline & Surgency & -0.81 & -1.11 & -0.50 & 0.000 & 658 \\
\hline & Negative affectivity & 0.11 & -0.20 & 0.41 & 0.497 & 658 \\
\hline & Effortful control & 0.69 & 0.31 & 1.08 & 0.000 & 658 \\
\hline \multicolumn{7}{|l|}{ Home level } \\
\hline \multirow[t]{9}{*}{ Parental beliefs and attitudes } & $\begin{array}{l}\text { Parental self-efficacy for activating child for physical } \\
\text { activity (PA) }\end{array}$ & -0.09 & -0.18 & -0.01 & 0.036 & 709 \\
\hline & Parental self-efficacy for limiting children's screen time & 0.07 & -0.00 & 0.13 & 0.052 & 712 \\
\hline & \multicolumn{6}{|c|}{ Parental attitude on importance of physical activity (ref: somewhat disagree) } \\
\hline & Neither agree or disagree & -0.51 & -2.53 & 1.51 & 0.619 & 715 \\
\hline & Somewhat agree & -0.63 & -2.49 & 1.22 & 0.503 & \\
\hline & Strongly agree & -1.09 & -2.95 & 0.76 & 0.248 & \\
\hline & $\begin{array}{l}\text { Parental attitude on societal pressures regarding } \\
\text { screen time }\end{array}$ & -0.00 & -0.09 & 0.08 & 0.960 & 710 \\
\hline & $\begin{array}{l}\text { Parental perceived barriers related to children's } \\
\text { outside PA }\end{array}$ & 0.13 & 0.06 & 0.02 & 0.001 & 711 \\
\hline & $\begin{array}{l}\text { Parental beliefs of unhealthy energy balance-related } \\
\text { behaviors (EBRBs) as a problem }\end{array}$ & -0.07 & -0.47 & 0.32 & 0.724 & 712 \\
\hline \multirow[t]{10}{*}{ Parenting practices } & Rules for limiting children's screen time & 0.43 & -0.19 & 1.04 & 0.173 & 685 \\
\hline & $\begin{array}{l}\text { Parental practice on allowing child to run around } \\
\text { inside }\end{array}$ & 0.09 & -0.23 & 0.40 & 0.586 & 715 \\
\hline & \multicolumn{6}{|c|}{ Parental screen use in front of children (ref: high parental screen use) } \\
\hline & Low & -0.47 & -1.14 & 0.20 & 0.171 & 714 \\
\hline & Middle & -0.56 & -1.22 & 0.11 & 0.103 & \\
\hline & Parental physical activity in front of children & -0.09 & -0.31 & 0.13 & 0.420 & 717 \\
\hline & Frequent co-visits in PA places & -0.12 & -0.12 & -0.04 & 0.002 & 717 \\
\hline & \multicolumn{6}{|l|}{ Mother's educational level (ref: highly educated) } \\
\hline & Low & 0.16 & -0.53 & 0.84 & 0.499 & 711 \\
\hline & Middle & -0.21 & -0.81 & 0.40 & 0.648 & \\
\hline \multicolumn{7}{|l|}{ Preschool level } \\
\hline \multirow[t]{7}{*}{ Principals' beliefs and attitudes } & \multicolumn{6}{|c|}{ Principals' personal interest in health (ref: neither disagree or agree) } \\
\hline & Somewhat agree & 0.54 & -0.22 & 1.29 & 0.162 & 654 \\
\hline & Strongly agree & 1.07 & 0.44 & 1.70 & 0.001 & \\
\hline & $\begin{array}{l}\text { Principals' attitude on the importance of increasing } \\
\text { children's physical activity }\end{array}$ & 0.02 & -1.34 & 1.37 & 0.982 & 665 \\
\hline & $\begin{array}{l}\text { Principals' attitude on the importance of decreasing } \\
\text { children's sedentary time }\end{array}$ & -0.23 & -2.24 & 1.77 & 0.820 & 665 \\
\hline & $\begin{array}{l}\text { Principals' self-efficacy for influencing children's } \\
\text { behaviors }\end{array}$ & -0.18 & -0.81 & 0.45 & 0.570 & 638 \\
\hline & Principals' beliefs of unhealthy EBRBs as a problem & 0.81 & 0.12 & 1.51 & 0.021 & 659 \\
\hline \multirow[t]{5}{*}{ Organizational policies and practices } & Frequency of visits in PA places & -0.19 & -0.37 & -0.01 & 0.047 & 665 \\
\hline & Screen-time policy & 0.16 & -0.03 & 0.35 & 0.103 & 665 \\
\hline & Guidance for families policy & -0.21 & -0.38 & -0.04 & 0.039 & 665 \\
\hline & Healthy PA policy & 0.06 & -0.04 & 0.13 & 0.200 & 665 \\
\hline & Active play possibility during free play & 0.29 & -0.48 & 1.06 & 0.466 & 674 \\
\hline
\end{tabular}


Table 2 Associations of each explanatory factor and children's sedentary time ( $\mathrm{min} / \mathrm{h}$ ) in multilevel linear regression models (Continued)

\begin{tabular}{|c|c|c|c|c|c|c|}
\hline Level of influence & Variable name & $\beta$ & Lower 95\% Cl & Upper 95\% Cl & $p$-value & $\mathrm{N}$ \\
\hline \multirow{2}{*}{$\begin{array}{l}\text { Preschool neighborhood socioeconomic } \\
\text { status (SES) (ref: high neighborhood SES) }\end{array}$} & Low & 0.62 & -0.65 & 1.89 & 0.339 & \multirow[t]{2}{*}{718} \\
\hline & Middle & 0.32 & -0.73 & 1.37 & 0.554 & \\
\hline
\end{tabular}

CI Confidence interval, PA Physical activity, EBRBS Energy balance-related behaviors, SES Socioeconomic status

associated with children's lower ST. Regarding the home setting, more frequent visits together in PA places $(p=$ 0.014) was associated with children's lower ST, whereas parental attitude about barriers related to children's physical activity outside $(p=0.032)$ was associated with children's higher ST. None of the preschool-level factors remained significant.

Fixed effects in the final model explained $29.8 \%$ of the variance (marginal $\mathrm{R}^{2}$ ) in children's ST. The proportion of variance explained in the model, including all fixed effects plus the random effect, was $53.5 \%$, which indicates that the random factor (preschool) caused much of the total variance. Table 4 shows the $29.8 \%$ of marginal variance separately for individual-, home- and preschoollevels. Approximately $11 \%$ of the variance in children's ST was attributed to factors related to the individual level; approximately $5 \%$ was attributed to home-level factors; and approximately $2 \%$ was attributed to preschool-level factors. Of the additional fixed factors, approximately $12 \%$ was attributed to the study season, and about $0.3 \%$ was attributed to the children's average attendance at preschool.

\section{Discussion}

The aim of this study was to examine individual-, homeand preschool level- factors associated with preschool children's ST. Additionally, it was studied how much individual-, home- and preschool- level factors explained the variance in children's ST. Of the individual level factors, being a boy and having a surgency-type temperament was associated with lower ST. Of the home-level factors, parental attitude about barriers related to children's PA outside was associated with children's higher ST, whereas more frequent visits together in PA places was associated with children's lower ST. None of the measured preschool-level factors remained significant in the final models. Together, these results suggest that individual-level factors explain more the variance in children's ST than home and preschool settings. Notably, the proportion of variance explained in ST, which included all fixed effects plus the random effect, was approximately $54 \%$. This high percentage indicates that the random factor (preschool) captured substantial amounts of additional variance. However, the variance of preschool factors used in this study remained low. This

Table 3 Final models: associations of explanatory factors and children's sedentary time $(\mathrm{min} / \mathrm{h})$ in multilevel linear regression models

\begin{tabular}{|c|c|c|c|c|c|}
\hline Level of influence & Variable name & $\beta$ & Lower $95 \% \mathrm{Cl}$ & Upper 95\% Cl & $\overline{p \text {-value }}$ \\
\hline \multirow[t]{3}{*}{ Individual level } & Gender & -1.07 & -1.61 & -0.52 & 0.001 \\
\hline & Surgency & -0.60 & -0.92 & -0.27 & 0.001 \\
\hline & Effortful control & 0.24 & -0.16 & 0.64 & 0.232 \\
\hline \multicolumn{6}{|l|}{ Home level } \\
\hline \multirow[t]{3}{*}{ Parental beliefs and attitudes } & $\begin{array}{l}\text { Parental self-efficacy for activating children to physical } \\
\text { activity (PA) }\end{array}$ & 0.18 & -0.24 & 0.61 & 0.403 \\
\hline & Parental self-efficacy for limiting children's screen time & 0.35 & -0.05 & 0.74 & 0.085 \\
\hline & Parental perceived barriers related to children's outside PA & 0.35 & 0.03 & 0.67 & 0.032 \\
\hline Parenting practices & Frequent co-visits in PA places & -0.14 & -0.26 & -0.03 & 0.014 \\
\hline \multicolumn{6}{|l|}{ Preschool level } \\
\hline \multirow[t]{4}{*}{ Principals' beliefs and attitudes } & \multicolumn{5}{|c|}{ Principals' personal interest in health (ref: neither agree or disagree) } \\
\hline & Somewhat agree & -0.18 & -3.58 & 3.21 & 0.916 \\
\hline & Strongly agree & 0.26 & -3.11 & 3.64 & 0.879 \\
\hline & $\begin{array}{l}\text { Principals' beliefs of unhealthy energy balance-related } \\
\text { behaviors (EBRBs) as a problem }\end{array}$ & 0.70 & -0.36 & 1.76 & 0.200 \\
\hline \multirow[t]{2}{*}{ Organizational policies and practices } & Frequency of visits in PA places & -0.20 & -0.44 & 0.04 & 0.104 \\
\hline & Guidance for families policy & 0.05 & -0.35 & 0.45 & 0.817 \\
\hline \multirow[t]{2}{*}{ Additional fixed factors } & Preschool time & -0.02 & -0.05 & 0.02 & 0.331 \\
\hline & Measurement season & 2.71 & 1.77 & 3.65 & 0.001 \\
\hline
\end{tabular}

CI Confidence interval, PA Physical activity, EBRBS Energy balance-related behaviors, SES Socioeconomic status 
Table 4 Percentage of variance explained by variance between fixed factors or by variance in full model

\begin{tabular}{|c|c|c|}
\hline $\begin{array}{l}\text { Level of } \\
\text { influence }\end{array}$ & Variable name & $\begin{array}{l}\% \text { explained } \\
\text { variance in full } \\
\text { model }\end{array}$ \\
\hline \multirow{3}{*}{$\begin{array}{l}\text { Individual level } \\
\text { factors }\end{array}$} & Gender & \multirow[t]{3}{*}{$10.7 \%$} \\
\hline & Surgency & \\
\hline & Effortful control & \\
\hline \multirow[t]{4}{*}{$\begin{array}{l}\text { Home level } \\
\text { factors }\end{array}$} & $\begin{array}{l}\text { Parental self-efficacy for activating } \\
\text { child to physical activity (PA) }\end{array}$ & \multirow[t]{4}{*}{$5.3 \%$} \\
\hline & $\begin{array}{l}\text { Parental self-efficacy for limiting } \\
\text { children's screen time }\end{array}$ & \\
\hline & $\begin{array}{l}\text { Parental perceived barriers related } \\
\text { to children's outside PA }\end{array}$ & \\
\hline & Frequent co-visits in PA places & \\
\hline \multirow{4}{*}{$\begin{array}{l}\text { Preschool level } \\
\text { factors }\end{array}$} & Principals' personal interest in health & \multirow[t]{4}{*}{$1.7 \%$} \\
\hline & $\begin{array}{l}\text { Principals' beliefs of unhealthy energy } \\
\text { balance-related behaviors (EBRBs) as a } \\
\text { problem }\end{array}$ & \\
\hline & Frequency of visits in PA places & \\
\hline & Guidance for families policy & \\
\hline \multirow{2}{*}{$\begin{array}{l}\text { Additional fixed } \\
\text { factors }\end{array}$} & Preschool time & $0.3 \%$ \\
\hline & Measurement season & $11.7 \%$ \\
\hline
\end{tabular}

difference indicates that we may not have measured the relevant preschool factors in our study to fully explain the potential variance in children's ST.

Two individual-level factors, namely being a boy and having high levels of surgency, were associated with lower ST. The individual-level factors also explained most of the variance in children's ST. Our findings support the results of many other studies: boys have less ST than girls [1]. Two recent studies concluded that activity temperament was associated with lower ST [52] whereas anxious temperament was associated with higher ST [53]. The studies also indicated that mothers with low income or who are overweight particularly dealt with children's challenging temperament traits by allowing their children use the television [54, 55]. In addition, Gubbels et al $[14,53]$ recognized that gender or temperament moderated the association between a preschool setting and children's movement behaviors. These previous studies have used different temperament instrument than this study. However, similar to our findings, these results underline that children's temperament influences their willingness to engage in movement behaviors already very early in life. Consequently, an improved strategy may involve better recognizing children's individual needs and developing intervention strategies that are tailored to their specific characteristics.

To our knowledge, no previous studies have included factors in both preschool and home setting in the same study as we did, and therefore making comparisons to previous studies is difficult. However, Schmutz et al stated that environmental factors, for example, children living in a dual-guardian household, concerns of neighborhood safety, apartment size and guardians with no sports-club membership explained approximately $17 \%$ of the variance in children's ST [52]. On the contrary, Hnatiuk et al found no other home-level factor associated with three-to-four-year-old children's ST, except a father's television viewing before $6 \mathrm{pm}$ [56]. However, no preschool-level factors were included in these studies. Nonetheless, Hesketh et al stated that British preschool explained little variance in children's anthropometry [57], and other studies had stated that a preschool setting explained 10 to $50 \%$ variance in children's PA [58-61]. However, less is known about variance in children's ST explained by preschool setting. Preschool care in Finland is widely regulated and standardized, ensuring similar levels of care for all children. Therefore, the preschool setting possibly has little influence in explaining the variance in children's ST. In addition, each setting may differ if ST is a personal choice or ST has environmental and social constraints [62]. Preschool setting may have multiple social norms for sitting and expectations for children to sit, for instance, morning circles, regular meal times or puzzle sessions [42], which are quite similar across preschools. Thus, few opportunities may exist for children's individual choice, causing little variance in children's ST.

Most of the factors in preschool settings were measured from the perspective of principals, but how well these items capture the daily practices conducted in preschool is questionable. For instance, various policies were measured from the perspective of principals; however, how aware early educators are of these policies is unknown, along with how much these policies are actually implemented in daily practices. It may therefore be that the questionnaire for principals captured inadequately the variables that were aimed to measure due to the difficulty in operationalizing the terms of attitudes, beliefs and policies. Overall, our results support the need to study other potential factors associated with children's ST in the preschool setting. In addition, of all the factors included in this study, study season had the highest percentage of variance. Evidence indicates seasonal variation in children's ST and PA, that is, children are more sedentary in rainy and dark weather during autumn and winter time [63-65]. This data was collected between early autumn and early spring, covering a wide variety of weather conditions.

Another research finding related to this theme was the association between parental perceived barriers related to children's outside PA and children's higher ST. The items included in this sum variable related to poor weather or difficulty of supervising a child outside. Previous 
qualitative studies have also highlighted parental attitudes on how poor weather, namely cold or rainy weather, limits children's PA and how a child is not allowed to play outside alone for safety reasons [66]. We did not measure in detail what type of weather parents consider is poor weather; however, the development of intervention strategies to account for these parental concerns regarding the weather or outside supervision is important as these concerns may limit children's possibilities to be active.

One study finding concerned the association between having frequent practices of visiting PA places with children in the home setting and lower children's ST. Similarly, frequent visits in PA places in the preschool setting was associated with lower children's ST in the individual models, although this association did not remain statistically significant in the final models. Overall, this practice of frequent visits to PA places may be a good target when developing intervention strategies aiming to reduce children's ST. Being active in PA places may provide better possibilities for children to have unstructured free play that allows them to move around, and therefore is associated with lower ST. Regular co-participation in PA, either inside or outside, benefits the development of children's social, self-regulation and motor skills, but also naturally provides healthy role-modelling opportunities to caregivers [67]. Most of the items included in these visiting PA places variables were activities conducted outside, for instance, in yards, playgrounds and nature. Previous studies have identified that time outdoors is associated with lower children's ST $[68,69]$. This study did not find any significant associations between SES factors and children's ST, which supports the findings of other studies that measured ST by objective measurement [24]. However, mediators (intervening factors) may exist between the associations of SES and children's ST. Conducting mediational analyses, despite non-significant overall associations, may enable an easier understanding of the mechanisms of influence [70]. In addition, some SES differences may exist in the presented co-participation practices. For instance, the previous study using this same study sample [71] found out that guardians with a low educational background reported more frequent visits with their child to their own yard, whereas guardians with high educational backgrounds reported more frequent visits with their children to indoor sports facilities. However, only frequent co-participation in own yard acted as mediator in the associations between guardians with a low educational background and children's ST. [71]

The current study has several strengths and limitations that should be accounted for. Multiple items that were similarly asked from the perspective of both guardians and preschools were measured. However, some of the measured items were not validated, and had quite low Cronbach alpha. In addition, other important factors that influence children's ST may exist, such as early educators' motivation and self-efficacy. For instance, previous study using this same study sample found out that early educators' practice often interrupting children's ST, more frequent physical activity (PA) theme weeks, and higher number of physical education (PE) lessons were associated with children's lower ST in preschools [72]. Our study did not cover physical environment factors either in home or preschool settings, which have most often been associated with children's ST at least in preschool setting [20]. However, multiple factors that are rarely measured were included. Compared to other studies among preschool-aged children, the sample size of this study was quite high and covered a variety of preschools around Finland. While a hip-placed accelerometer can provide ST over a prolonged period, they are less valid in distinguishing sedentary postures, such as lying and sitting, from other light-intensity activities performed while standing. Different definitions of ST, different used cut-points and different data reduction methods may explain some of the dissimilarity between our results and previous studies. In addition, it may be relevant to measure children's ST with multiple methods. Proxy-reports and observations may provide valuable additional knowledge of the specific SBs (e.g. reading, screen time) that cannot be captured with accelerometers. This knowledge is important as the correlates of specific SBs seem to be different than that of overall ST [22]. Our data is cross-sectional, which prevents drawing causal inferences. The detected associations between explanatory factors and outcome were relatively small. It may be that it was failed to find associations when one existed due to a lack of power and sample size. However, by including multiple levels of influence, especially using both home and preschool settings within the same study, our study introduced novel information about factors explaining the variance in preschool children's ST.

\section{Conclusion}

This study recognized multiple factors on individual, home and preschool levels that were associated with preschool children's ST. Children's individual characteristics such as gender and temperament were associated with children's ST, and explained more the variance in children's ST than settings.. Future strategies aiming to reduce children's ST should consequently tailor intervention strategies to children's individual characteristics, without forgetting the influence of home and preschool settings. The preschool-level factors included in this study explained little the variance in children's ST between preschools, possibly because the included 
measures did not capture the essential factors in preschool setting that influence children's ST. In conclusion,the development of improved methods of measuring the preschool-level factors is essential.

\section{Abbreviations}

DAGIS: Increased health and wellbeing in preschools; EBRBs: Energy balancerelated behaviors; PA: Physical activity; SB: Sedentary behavior; SD: Standard deviation; SES: Socioeconomic status; ST: Sedentary time

\section{Acknowledgements}

The authors thank the preschools, preschool personnel, and parents for their participation in the DAGIS study and the data collection.

\section{Authors' contributions}

SM participated in conducting statistical analyses, wrote the first draft of the manuscript, and revised new drafts based on input from co-authors. HK and RF participated in conducting the statistical analyses of this manuscript. SM, $H K, R F, A H, N S, M E$ and $E R$ participated in designing the study. $H K, R F, A H$, NS, ME and ER participated in interpreting the results of the data, and provided critical improvements to the first draft of manuscript. ER was the main responsible researcher and directed the data collection. All authors approved the final manuscript

\section{Funding}

The first author of this manuscript was financially supported by personal grants from the Juho Vainio Foundation and the Yrjö Jahnsson Foundation. The DAGIS study was financially supported by the Folkhälsan Research Center, the University of Helsinki, the Ministry of Education and Culture in Finland, Medicinska understödsföreningen för Liv och hälsa, the Academy of Finland (number 288038, number 285439), the Juho Vainio Foundation, the Päivikki and Sakari Sohlberg Foundation, the Signe and Ane Gyllenberg Foundation, and The Finnish Cultural Foundation/South Ostrobothnia Regional Fund.

\section{Availability of data and materials}

Researchers interested in the data from this study may contact the principal investigator Eva Roos at eva.roos@folkhalsan.fi.

\section{Ethics approval and consent to participate}

Ethical approval was provided by the University of Helsinki Ethical Review Board in the Humanities and Social and Behavioral Sciences. A short letter with information about the study and the possibility to deny further participation was sent out to all invited parents. A parent or legal guardian of each participant provided an informed consent.

\section{Consent for publication}

Not applicable.

\section{Competing interests}

The authors declare that they have no competing interest.

\section{Author details}

${ }^{1}$ Folkhälsan Research Centre, Samfundet Folkhälsan, Topeliuksenkatu 20, 00250 Helsinki, Finland. ${ }^{2}$ Faculty of Social Sciences, University of Helsinki, P.O.box 66, Fl-00014 University of Helsinki, Helsinki, Finland. ${ }^{3}$ Department of Food and Environmental Sciences, University of Helsinki, P.O. Box 66, $\mathrm{Fl}-00014$ University of Helsinki, Helsinki, Finland. ${ }^{4}$ Faculty of Educational Sciences, University of Helsinki, P.O.box 66, FI-00014 University of Helsinki, Helsinki, Finland. ${ }^{5}$ Clinicum, Department of Public Health, University of Helsinki, P.O.box 66, Fl-00014 Helsinki, Finland.

\section{Received: 14 September 2019 Accepted: 29 January 2020}

Published online: 07 February 2020

\section{References}

1. Pereira JR, Cliff DP, Sousa-Sa E, Zhang Z, Santos R. Prevalence of objectively measured sedentary behavior in early years: Systematic review and metaanalysis. Scand J Med Sci Sports. 2019;29(3):308-28. https://doi.org/10.1111/ sms.13339. Epub 2018 Dec 18.
2. Tremblay MS, Aubert S, Barnes JD, Saunders TJ, Carson V, Latimer-Cheung AE, Chastin SFM, Altenburg TM, Chinapaw MJM. SBRN Terminology Consensus Project Participants: Sedentary Behavior Research Network (SBRN) - Terminology Consensus Project process and outcome. Int J Behav Nutr Phys Act. 2017;14(1):75-017-0525-8.

3. Chau JY, Grunseit AC, Chey T, Stamatakis E, Brown WJ, Matthews CE, Bauman AE, van der Ploeg HP. Daily sitting time and all-cause mortality: a meta-analysis. PLoS One. 2013;8(11):e80000.

4. Ekelund U, Steene-Johannessen J, Brown WJ, Fagerland MW, Owen N, Powell KE, Bauman A, Lee IM. Lancet Physical Activity Series 2 Executive Committe, Lancet Sedentary Behaviour Working Group: Does physical activity attenuate, or even eliminate, the detrimental association of sitting time with mortality? A harmonised meta-analysis of data from more than 1 million men and women. Lancet. 2016;388(10051):1302-10.

5. Patterson R, McNamara E, Tainio M, de Sa TH, Smith AD, Sharp SJ, Edwards P, Woodcock J, Brage S, Wijndaele K. Sedentary behaviour and risk of allcause, cardiovascular and cancer mortality, and incident type 2 diabetes: a systematic review and dose response meta-analysis. Eur J Epidemiol. 2018; 33(9):811-29.

6. Cliff DP, Hesketh KD, Vella SA, Hinkley T, Tsiros MD, Ridgers ND, Carver A, Veitch J, Parrish AM, Hardy LL, Plotnikoff RC, Okely AD, Salmon J, Lubans DR. Objectively measured sedentary behaviour and health and development in children and adolescents: systematic review and meta-analysis. Obes Rev. 2016;17(4):330-44.

7. Jones RA, Hinkley T, Okely AD, Salmon J. Tracking physical activity and sedentary behavior in childhood: a systematic review. Am J Prev Med. 2013; 44(6):651-8.

8. De Craemer M, Lateva M, lotova V, De Decker E, Verloigne M, De Bourdeaudhuij I, Androutsos O, Socha P, Kulaga Z, Moreno L, Koletzko B, Manios Y, Cardon G. ToyBox-study group: Differences in energy balancerelated behaviours in European preschool children: the ToyBox-study. PLoS One. 2015;10(3):e0118303.

9. Verloigne M, Loyen A, Van Hecke L, Lakerveld J, Hendriksen I, De Bourdheaudhuij I, Deforche B, Donnelly A, Ekelund U, Brug J, van der Ploeg HP. Variation in population levels of sedentary time in European children and adolescents according to cross-European studies: a systematic literature review within DEDIPAC. Int J Behav Nutr Phys Act. 2016;13(1):69-016-0395-5.

10. O'Brien KT, Vanderloo LM, Bruijns BA, Truelove S, Tucker P. Physical activity and sedentary time among preschoolers in centre-based childcare: a systematic review. Int J Behav Nutr Phys Act. 2018;15:117.

11. Bronfenbrenner $U$. The ecology of Human Development: experiments by nature and design. Cambridge,MA: Harward University press; 1979.

12. Owen N, Sugiyama T, Eakin EE, Gardiner PA, Tremblay MS, Sallis JF. Adults' sedentary behavior determinants and interventions. Am J Prev Med. 2011;41(2):189-96.

13. Sallis JF, Owen N, Fisher EB: Ecological models of health behavior. In Health behavior and health education: theory, research, and practice. 4th ed. edition. Edited by Glanz K, Rimer BK, Viswanath KE. San Francisco CA: Jossey-Bass; 2008:465-482.

14. Gubbels JS, Van Kann DH, de Vries NK, Thiijs C, Kremers SP. The next step in health behavior research: the need for ecological moderation analyses - an application to diet and physical activity at childcare. Int J Behav Nutr Phys Act. 2014;11(1):52 5868-11-52.

15. Davison KK, Birch LL. Childhood overweight: a contextual model and recommendations for future research. Obes Rev s. 2001;2:159-71.

16. Edwardson C, Gorely T. Parental influences on different types and intensities of physical activity in youth: A systematic Review. Psychol Sport Exerc. 2010;11:522-35.

17. Ward S, Belanger M, Donovan D, Carrier N. Systematic review of the relationship between childcare educators' practices and preschoolers' physical activity and eating behaviours. Obes Rev. 2015;16(12):1055-70.

18. Hinkley T, Salmon J, Okely AD, Trost SG. Correlates of sedentary behaviours in preschool children: a review. Int J Behav Nutr Phys Act. 2010;7:66 5868-7-66.

19. Hildebrand M, Oglund GP, Wells JC, Ekelund U. Prenatal, birth and early life predictors of sedentary behavior in young people: a systematic review. Int J Behav Nutr Phys Act. 2016;13:63-016-0389-3.

20. Tonge KL, Jones RA, Okely AD. Correlates of children's objectively measured physical activity and sedentary behavior in early childhood education and care services: A systematic review. Prev Med. 2016;89:129-39. 
21. Xu H, Wen LM, Rissel C. Associations of parental influences with physical activity and screen time among young children: a systematic review. J Obes 2015, 2015;546925:-546925.

22. Downing KL, Hinkley T, Salmon J, Hnatiuk JA, Hesketh KD. Do the correlates of screen time and sedentary time differ in preschool children? BMC Public Health. 2017;17(1):285-017-4195-x.

23. Krist L, Bürger C, Ströbele-Benschop N, Roll S, Lotz F, Rieckmann N, MüllerNordhorn J, Willich SN, Müller-Riemenschneider F. Association of individual and neighbourhood socioeconomic status with physical activity and screen time in seventh-grade boys and girls in Berlin, Germany: a cross-sectional study. BMJ Open. 2017;7(12):e017974

24. Cameron AJ, Spence AC, Laws R, Hesketh KD, Lioret S, Campbell KJ. A Review of the Relationship Between Socioeconomic Position and the EarlyLife Predictors of Obesity. Curr Obes Rep. 2015;4(3):350-62.

25. Cubbin C, Hadden WC, Winkleby MA. Neighborhood context and cardiovascular disease risk factors: the contribution of material deprivation. Ethn Dis. 2001;11(4):687-700.

26. Laaksonen M, Talala KF, Martelin TF, Rahkonen OF, Roos EF, Helakorpi SF, Laatikainen TF, Prattala R. Health behaviours as explanations for educational level differences in cardiovascular and all-cause mortality: a follow-up of 60 000 men and women over 23 years. Eur J Pub Health. 2008;18(1):38-43.

27. Ross CE, Mirowsky J. Neighborhood disadvantage, disorder, and health. J Health Soc Behav. 2001 Sep;42(3):258-76.

28. Gebremariam MK, Altenburg TM, Lakerveld J, Andersen LF, Stronks K, Chinapaw MJ, Lien N. Associations between socioeconomic position and correlates of sedentary behaviour among youth: a systematic review. Obes Rev. 2015;16(11):988-1000.

29. Bingham DD, Costa S, Hinkley T, Shire KA, Clemes SA, Barber SE. Physical Activity During the Early Years: A Systematic Review of Correlates and Determinants. Am J Prev Med. 2016;51(3):384-402.

30. Lehto $E$, Ray C, Vepsäläinen $H$, Korkalo L, Lehto R, Kaukonen R, Suhonen E, Nislin M, Nissinen K, Skaffari E, Koivusilta L, Sajaniemi N, Erkkola M, Roos E. Increased Health and Wellbeing in Preschools (DAGIS) Study - Differences in Children's Energy Balance-Related Behaviors (EBRBs) and in Long-Term Stress by Parental Educational Level. Int J Environ Res Public Health. 2018;15(10).

31. Määttä S, Lehto R, Nislin M, Ray C, Erkkola M, Sajaniemi N, Roos E. Increased health and wellbeing in preschools (DAGIS): rationale and design for a randomized control. BMC Public Health. 2015;15(1):402.

32. Janssen X, Cliff DP, Reilly JJ, Hinkley T, Jones RA, Batterham M, Ekelund U, Brage S, Okely AD. Predictive validity and classification accuracy of ActiGraph energy expenditure equations and cut-points in young children. PLoS One. 2013:8(11):e79124.

33. Pate RR, Almeida MJ, Mclver KL, Pfeiffer KA, Dowda M. Validation and calibration of an accelerometer in preschool children. Obes(Silver Spring). 2006:14(11):2000-6.

34. Puyau MR, Adolph AL, Vohra FA, Butte NF. Validation and calibration of physical activity monitors in children. Obes Res. 2002;10(3):150-7.

35. Cliff DP, Reilly JJ, Okely AD. Methodological considerations in using accelerometers to assess habitual physical activity in children aged 0-5 years. J Sci Med Sport. 2009;12(5):557-67.

36. Evenson KR, Catellier DJ, Gill K, Ondrak KS, McMurray RG. Calibration of two objective measures of physical activity for children. J Sports Sci. 2008;26(14):1557-65.

37. Ridgers ND, Salmon J, Ridley K, O'Connell E, Arundell L, Timperio A. Agreement between activPAL and ActiGraph for assessing children's sedentary time. Int J Behav Nutr Phys Act. 2012;9:15 5868-9-15.

38. Trost SG, Loprinzi PD, Moore R, Pfeiffer KA. Comparison of accelerometer cut points for predicting activity intensity in youth. Med Sci Sports Exerc. 2011:43(7):1360-8.

39. Putnam SP, Rothbart MK. Development of Short and Very Short forms of the Children's Behavior Questionnaire. J Pers Assess. 2006;87(1):103-13.

40. Carson V, Janssen I. Associations between factors within the home setting and screen time among children aged $0-5$ years: a cross-sectional study. BMC Public Health. 2012;12:539 2458-12-539.

41. Crawford DA, Ball K, Cleland VJ, Campbell KJ, Timperio AF, Abbott G, Brug J, Baur LA, Salmon JA. Home and neighbourhood correlates of BMI among children living in socioeconomically disadvantaged neighbourhoods. $\mathrm{Br} J$ Nutr. 2012;107(7):1028-36.

42. Määttä S, Ray C, Roos G, Roos E. Applying a Socioecological Model to Understand Preschool Children's Sedentary Behaviors from the Viewpoints of Parents and Preschool Personnel. Early Childhood Educ J. 2016;44(5):491-502.
43. Ray C, Määttä S, Roos G, Roos E. Vanhempien käsityksiä päiväkotiikäisten lasten kasvisten, hedelmien ja sokeripitoisten elintarvikkeiden syömiseen vaikuttavista tekijöistä [Parents perceptions about factors influencing preschool children's intake of fruit and vegetables, and sugar-enriched foods]. Varhaiskasvatuksen Tiedelehti (J Early Child Educ Res). 2016;5(1):115-35.

44. van Ansem WJC, CTM S, Rodenburg G, van D M. Maternal educational level and children's healthy eating behaviour: role of the home food environment (cross-sectional results from the INPACT study). Int J Behav Nutrit Phys Act. 2014;11:113.

45. Winkleby MA, Jatulis DE, Frank E, Fortmann SP. Socioeconomic status and health: how education, income, and occupation contribute to risk factors for cardiovascular disease. Am J Public Health. 1992;82(6):816-20.

46. Ward D, Hales D, Haverly K, Marks J, Benjamin S, Ball S, Trost S. An instrument to assess the obesogenic environment of child care centers. Am J Health Behav. 2008:32(4):380-6.

47. Androutsos O, Apostolidou EF, lotova VF, Socha PF, Birnbaum JF, Moreno L FAU,- De Bourdeaudhuij, De Bourdeaudhuij IF, Koletzko BF, Manios Y: Process evaluation design and tools used in a kindergartenbased, family-involved intervention to prevent obesity in early childhood. The ToyBox-study. Obes Rev s 2014 Aug;15 Suppl 3:74-80. doi: https://doi.org/10.1111/obr.12185.

48. Manios Y, Androutsos OF, Katsarou CF, lotova VF, Socha PF, Geyer CF, Moreno LF, Koletzko B FAU,- De Bourdeaudhuij, I: Designing and implementing a kindergarten-based, family-involved intervention to prevent obesity in early childhood: the ToyBox-study. Obes Rev s 2014;15 Suppl 3:513. doi: https://doi.org/10.1111/obr.12175.

49. Geiser C. Data Analysis with Mplus: New York. NY: The Guilford Press; 2012.

50. Stride C. Multilevel Modelling using Mplus. London: Falcon Training/ Figure It Out; 2013.

51. Nakagawa S, Schielzeth H. A general and simple method for obtaining R2 from generalized linear mixed-effects models. Methods Ecol Evol. 2013;4(2):133-42.

52. Schmutz EA, Leeger-Aschmann CS, Radtke T, Muff S, Kakebeeke TH, Zysset AE, Messerli-Burgy N, Stulb K, Arhab A, Meyer AH, Munsch S, Puder JJ, Jenni OG, Kriemler S. Correlates of preschool children's objectively measured physical activity and sedentary behavior: a cross-sectional analysis of the SPLASHY study. Int J Behav Nutr Phys Act. 2017;14(1):1 -016-0456-9.

53. Gubbels JS, Van Kann DH, Cardon G, SPJ K. Activating Childcare Environments for All Children: the Importance of Children's Individual Needs. Int J Environ Res Public Health. 2018;15(7):1400.

54. Radesky JS, Silverstein M, Zuckerman B, Christakis DA. Infant self-regulation and early childhood media exposure. Pediatr. 2014;133(5):e1172-8.

55. Thompson AL, Adair LS, Bentley ME. Maternal characteristics and perception of temperament associated with infant TV exposure. Pediatr. 2013;131(2):e390-7.

56. Hnatiuk JA, Hesketh KR, van Sluijs EM. Correlates of home and neighbourhood-based physical activity in UK 3-4-year-old children. Eur J Pub Health. 2016 Dec;26(6):947-53. https://doi.org/10.1093/eurpub/ckw067.

57. Hesketh KR, Benjamin-Neelon S, van Sluijs E, MF.: How does the UK childcare energy-balance environment influence anthropometry of children aged 3 to 4 years? A cross-sectional exploration. BMJ Open 2018, 8(7):e021520.

58. Olesen LG, Kristensen PL, Korsholm L, Froberg K. Physical activity in children attending preschools. Pediatr. 2013;132(5):e1310-8.

59. Pate RR, Pfeiffer KA, Trost SG, Ziegler P, Dowda M. Physical activity among children attending preschools. Pediatr. 2004;114(5):1258-63.

60. Vanderloo LM, Tucker P, Johnson AM, van Zandvoort M, Burke SM, Irwin JD: The influence of centre-based childcare on preschoolers' physical activity levels: a cross-sectional study. Int J Environ Res Public Health 2014, 11(2):1794-1802.

61. Tucker $P$, Vanderloo LM, Burke SM, Irwin JD, Johnson AM. Prevalence and influences of preschoolers' sedentary behaviors in early learning centers: a cross-sectional study. BMC Pediatr, 2015;15:128.

62. Spence JC, Rhodes RE, Carson V. Challenging the Dual-Hinge Approach to Intervening on Sedentary Behavior. Am J Prev Med. 2017;52(3):403-6.

63. Carson V, Spence J, Cutumisu N, Boulé N, Edwards J. Seasonal Variation in Physical Activity Among Preschool Children in a Northern Canadian City. Res Q Exerc Sport. 2010;81:392-9.

64. Gracia-Marco L, Ortega FB, Ruiz JR, Williams CA, Hagstromer M, Manios Y, Kafatos A, Beghin L, Polito A, De Henauw S, Valtuena J, Widhalm K, Molnar D, Alexy U, Moreno LA, Sjostrom M, Helena Study Group: Seasonal variation in physical activity and sedentary time in different European regions. HELENA study 4 kapin 2013, 31(16):1831-1840. 
65. Harrison F, Goodman A, van Sluijs EMF, Andersen LB, Cardon G, Davey R, Janz KF, Kriemler S, Molloy L, Page AS, Pate R, Puder JJ, Sardinha LB, Timperio A, Wedderkopp N, Jones AP. on behalf the ICAD collaborators: Weather and children's physical activity; how and why do relationships vary between countries? Int J Behav Nutr Phys Act. 2017;14(1):74-017-0526-7.

66. Hesketh KR, Lakshman R, van Sluijs EMF. Barriers and facilitators to young children's physical activity and sedentary behaviour: a systematic review and synthesis of qualitative literature. Obes Rev. 2017 Sep;18(9):987-1017. https://doi.org/10.1111/obr.12562.

67. Uijtdewilligen L, Brown HE, Muller-Riemenschneider F, Lim YW, Brage S, van Sluijs EM. A systematic review of methods to measure family coparticipation in physical activity. Obes Rev. 2017;18(12):1454-72.

68. Lindsay AC, Greaney ML, Wallington SF, Mesa T, Salas C. A review of early influences on physical activity and sedentary behaviors of preschool-age children in high-income countries. J Spec Pediatr Nurs. 2017;22(3). https:// doi.org/10.1111/jspn.12182. Epub 2017 Apr 13.

69. Truelove S, Bruijns BA, Vanderloo LM, O'Brien KT, Johnson AM, Tucker P. Physical activity and sedentary time during childcare outdoor play sessions: A systematic review and meta-analysis. Prev Med. 2018;108:74-85.

70. Cerin E, Mackinnon DP. A commentary on current practice in mediating variable analyses in behavioural nutrition and physical activity. Public Health Nutr. 2009;12(8):1182-8.

71. Määttä S, Ray C, Vepsäläinen H, Lehto E, Kaukonen R, Ylönen A, Roos E. Parental Education and Pre-School Children's Objectively Measured Sedentary Time: The Role of Co-Participation in Physical Activity. Int J Environ Res Public Health. 2018;15(2). https://doi.org/10.3390/ ijerph15020366.

72. Määttä S, Konttinen H, Lehto R, Haukkala A, Erkkola M, Roos E. Preschool Environmental Factors, Parental Socioeconomic Status, and Children's Sedentary time: An examination of Cross-Level interactions. Int J Environ Res Public Health. 2019;16(1):46. https://doi.org/10.3390/ijerph16010046

\section{Publisher's Note}

Springer Nature remains neutral with regard to jurisdictional claims in published maps and institutional affiliations.

Ready to submit your research? Choose BMC and benefit from:

- fast, convenient online submission

- thorough peer review by experienced researchers in your field

- rapid publication on acceptance

- support for research data, including large and complex data types

- gold Open Access which fosters wider collaboration and increased citations

- maximum visibility for your research: over $100 \mathrm{M}$ website views per year

At $\mathrm{BMC}$, research is always in progress.

Learn more biomedcentral.com/submissions 